\title{
Efficiency of Resistant Types of Soft Spring Wheat Grades to Leaf Rust
}

\author{
Shermahan K Shapalov ${ }^{1}$, Zhanar S.Tileubayeva², Meruyert S. Kurmanbayeva ${ }^{3}$, \\ Amangeldy O. Sarbaev ${ }^{4}$, K.R. Hidirov ${ }^{5}$, A.S.Naukenova ${ }^{5}$ and G.B.Alpamysova ${ }^{5}$ \\ Kazakh National Agricultural University ${ }^{1}$, Kazakh State Women’s Teacher Training University ${ }^{2}$, \\ Al Farabi Kazakh National University ${ }^{3}$, Kazakh Research Institute of Agriculture \\ and crop production ${ }^{4}$ Almaty, Kazakhstan, M.Ayezov south Kazahstan State University ${ }^{5}$ \\ Correspondence: Meruyert S. Kurmanbayeva, Al Farabi Kazakh National University, Almaty, \\ Kazakhstan.
}

http://dx.doi.org/10.13005/bbra/2014

(Received: 03 January 2016; accepted: 16 February 2016)

\begin{abstract}
Types of wheat rust are among the most harmful diseases, which leads to a significant loss of yields. Under favorable conditions, the development of the disease can reduce the yield to $45 \%$ or more. During epiphytotic development, it covers an area of up to $1.5-2.0 \mathrm{mln}$ ha and reduces the yields to $20-70 \%$. Pathogens types of rust fungus diseases adapted to different climatic conditions, resulting in leaf rust meet annually and in all regions of wheat cultivation. Farms generally accepted crop protection from the disease by chemical means. However, the use of fungicides - is not only very costly, it is also environmentally safe, both for the near biological objects, and consumers received products. The most efficient and environmentally acceptable way to protect against the disease - a genetic. However, the gene pool of wheat resistance genes to rusts (P.recondita f. Sp. Tritici Rob. Ex Desm., P.graminis, P.striiformis) greatly exhausted, and every year there are new pathotypes of the pathogen able to overcome previous effective resistance genes (Lr, Sr, Yr-genes). Therefore, the stability test of wheat varieties and breeding for resistance is conducted in a continuous loop. The extension of genetic diversity of spring bread wheat varieties is possible by the involvement in hybridization of the new sources of valuable biological and economical features from the world's gene pool. The article on artificial infectious background investigation conducted spring wheat varieties for resistance to rusts and selected for the selection of resistant forms of immunity. The research revealed the forms resistant to leaf and stem rust and featuring high yielding potential.
\end{abstract}

Key words: spring wheat varieties, leaf brown rust

The agent of brown leaf rust Puccinia recondita Roberge ex Desmaz f.sp. tritici Eriks et Henn is adapted to various climatic conditions, as a result, the leaf rust can be met annually in all regions of cultivated wheat. The brown leaf rust of wheat remains one of the most harmful diseases despite the significant progress in studying the nature resistance of the genus, structure and

\footnotetext{
* To whom all correspondence should be addressed. Tel.: + 77752961044;

E-mail: kurmanbaevakz@mail.ru
}

variability of pathogen populations and development in practical selection on resistance . Use of genetically caused resistance is the most economical and therefore, the most preferable method of decrease in losses of a crop. There are various programs of creation wheat grades that are resistant to rust for a long time and the programs are based on use of genes of different resistance level (. Plotnikova L.Ya. \& Shtrubey T.Yu., 2012, Mikhaylova L.A., 2003, Makarov A.A., Kovalenko E.D., Solomatin D. A., Matorina N. M., 2003).

In system of the integrated protection of the main crops against diseases the leading role 
belongs to steady grades. Van der Planck formulated the known theory about vertical and horizontal type of stability. Information on the main features and properties is necessary for reasonable use in donor stability selection. Vertical stability can provide full protection against an illness, and is usually effective against one kind of parasites and inefficient against others. It can put a strong pressure on population of a parasite, leading to accumulation of virulent pathotypes or to emergence of new races with new genes of virulence (Kolmer J.A., 1996, McIntosh R.A., 2009, Kovalenko E.D., A.I., Kiselyov M. I. Pearl., Kolomiyets T.M., Sherbik A.A., 2012, Makarov A.A., Solomatin D. A., Strizhekozin Yu.A., 1998).

In some cases vertical stability can change depending on temperature and light conditions. It can be on all stages of ontogenesis and be high or moderate. This stability is controlled by mono - or oligogenes and is often caused by reaction of supersensitivity (Kisileva M. I, E.D. Kovalenko E.D, Mitrofanov O. P., 2015, Seytkhozhayev A.I., Kolesnikova L.I., Dyusibayeva E.N., 2015, Knaus, Yulia Konstantinovna, 2009). Grades with racespecific resistance put the strong pressure on pathogen populations, which leads to accumulation of virulent pathotype of a mushroom on such grades. According to researchers, it is enough to have about 12 thousand hectares of production crops of a new wheat grade with specific resistance to rust for a new mushroom 6 pathotype in crops that would strike that grade. Particular zones have a great influence on intensity of this process that accelerate or slow down mutational changes in a pathogen genotype, on which eventually the durability of the grade in production depends. The durability of the grade also increases because of introduction to its genotype of more than two effective genes of specific stability. Grades with nonspecific resistance remain in production for longer time. They are stroke by many known pathogene pathotypes in a concrete zone, but the level of the strike is not usually high and big decrease in productivity does not happen (Ganiyev M. M., Nedorezkov V.D., Ganiyev P.M., 2002, Gorlenko M. V., Rubin. B. A., 2002). Grades with nonspecific resistance type, happens much more often and contain genes of specific and nonspecific resistance, provide a certain genetic balance between the main plant and a pathogen. Thus, there is no pressure of a new grade on pathogen population for the vegetative period, it prevents development of strong epiphytoties on crops of such grades and allows to use not chemical, but biological preparations that are important for health care and protection of the environment.

Phytopathologic manifestation of nonspecific resistance is the weak or moderate prevalence of plants irrespective of a racial variety of a parasite, i.e. this resistance is equally shown in relation to all races of a pathogen. Nonspecific resistance reduces effect of an infection after it has occurred. The grade illness with such type of resistance can develop slowly and the crop still does not decrease significantly. Nonspecific resistance does not provide full protection of the main plant, but it is more stable. The same or different genes responsible for resistance can be on various stages of ontogenesis of plants. Therefore can be distinguished germ, or juvenile and age genes of resistance. Juvenile genes are most often met in all phases of development of a plant, and age genes- only from a certain phase of an adult plant. Wheat grades, steady against a rust in a field, are often susceptible at their studying in a phase of sprouts. Rusts differently strike grades in different phases of development of plants. Influence of genes of wheat resistance on diseases can depend on the genetic environment in which they are located. External conditions, first of all, the temperature, have impact on genes of wheat resistance to diseases. There is numerous information on change of type and intensity of strike of plants types by a rust and other diseases depending on temperature (Kolmer J.A., Liu J.Q., 2000, Markelova T.S., 2007).

No matter which resistance is used in selection, it is important that at its implementation factors of a genetic variety of the created grades on resistance, its durability and efficiency were considered. A condition for temporary use of a genetic variety on features of qualitative and quantitative resistance is creation of the most extensive collection of the donors used in selection. (Konovalova N. E., Semenova L.P., Sorokina G. K., Shchekotkova T.V., Suzdal M.V., Bukanova V. K., A.I., Gorbunov Yu.V., Rogozhina E.M., Solomatin D. A., Koroleva L.A., Schelko L.G. ,1977, Roelfs A.P., Singh R.P., Sari E.E., 1992). So 
far the stock of effective genes of resistance is not sufficient for ensuring due level of a variety and qualitative the quantity of effective Lr-genes of resistance to the activator of brown leaf rust is reduced every year. Continuous search of such genes is necessary. It is actual and significant for selection.

Due to this problem it is necessary to search for new sources of resistance which are of interest to selection. With this purpose there have been carried out immunological researches and an assessment of grades of wheat to a brown leaf rust.

\section{MATERIALSAND METHODS}

As seed material we used grades of soft spring-wheat. Infectious material was the uredospore of brown leaf rust collected on experiment fields of collection grades and also from the struck wild-growing cereals. The experiments were held under the conditions of a greenhouse. The shoots of plants, received at $+22 \ldots+240 \mathrm{C}$ were inoculated by local populations of brown leaf rust with the help of a spraying method. Processes of infection of plants, creation of the damp camera were carried out according to N. E. Konovalova's technique, etc. (Mains E.E., Jackson H.S., 1926) (Figure 1).

The type of strike of plants by leaf rust was determined by a five-point scale of E.E.Mains, H.S.Jackson (Peterson R.F., Campbell A.B., Hannah A.E., 1949). 0 point belongs to immune type, 1-2 points - steady, and 3-4 points - to susceptible type. Intensity of strike of plants was determined by the modified scale of Kobba (a scale of R.F.Peterson, A.B.Campbell, A.E.Hannah) (Konovalova N. E., Semenova L.P., Sorokina G. K., Shchekotkova T.V., Suzdalskaya M.V., Bukanova V. K., A.I., Gorbunov Yu.V., Rogozhina E.M., Solomatin D. A., Koroleva L.A., Schelko L.G., 1977).

\section{RESULTSAND DISCUSSION}

Research under field and greenhouse conditions has been held with the purpose of identification age and germ (juvenile) resistance of soft spring-wheat grades to brown leaf rust . The assessment of age resistance of grades is carried out in a phase of the beginning and dairy- wax ripeness of plants. The results showed that the grades of soft spring-wheat had moderate and average resistance (2-3 points, $10-40 \%$ ) in a phase of heading and in the phase of dairy and wax ripeness in strong degree are stroke by leaf rust (60-80\%). Moderate resistance was observed in a grade Erythrospermum 55/94. On a scale the type of strike was made 2 points, $20 \%$. Among grades of soft wheat on age resistance to a brown leaf rust the grade Omsk 37 was different. Plants were absolutely healthy, without change of leaf colors (Figure 2).

As it is known, development of brown leaf rust requires only two factors - presence of drop liquid moisture on plants and a certain air temperature. According to meteorological researches, at the beginning of spring (March, April) the rainfall of $93 \mathrm{~mm}-112,7$ of mm exceeded the norm twice, however, average monthly temperature was $3,8-10,40 \mathrm{C}$. The ratio of the sums of humidity, optimum for development of a brown leaf rust and air temperatures was in June. Air temperature was 22,3-22oC, exceeding rainfall higher than usual $-38,7 \mathrm{~mm}$. Correlation of disease manifestation has been noted in this period.

During the research of germ resistance of grades of soft spring-wheat, there were used uredospores of brown leaf rust allocated from leaves of the struck grades as infectious materials. Infection of plants was carried out in a phase of 10-12-day sprouts of wheat by suspension of mushroom uredospores with addition of one drop

Table 1. Immunological assessment of soft spring-wheat grades

\begin{tabular}{|c|c|c|}
\hline \multirow[t]{2}{*}{ The grade name } & \multicolumn{2}{|c|}{$\begin{array}{l}\text { Development of brown } \\
\text { leaf rust, score \% }\end{array}$} \\
\hline & 1 record & 2 record \\
\hline Akmola 2 & $3 / 10$ & $3 / 50$ \\
\hline Astana & $2 / 5$ & $3 / 20$ \\
\hline Bashkir 24 & $2 / 5$ & $3 / 20$ \\
\hline Omsk 20 & 0 & $1 / 5$ \\
\hline Omsk 37 & 0 & $1 / 5$ \\
\hline Ikar & $2 / 20$ & $3 / 40$ \\
\hline Severyanka & 0 & $3 / 20$ \\
\hline Terce & 0 & $2 / 5$ \\
\hline Steppe 62 & $3 / 5$ & $4 / 10$ \\
\hline Shagala & $4 / 10$ & $4 / 40$ \\
\hline Saratov 29 & $4 / 40$ & $4 / 60$ \\
\hline
\end{tabular}


of the Twin-80. As a result of the obtained data the studied grades of the soft spring-wheat are grouped by resistance to brown leaf rust. Generally all the studied grades of soft spring-wheat showed susceptibility, and the reaction on a scale made 34 points, $40-60 \%$.

Among the studied grades of soft springwheat germ and age resistance to brown leaf rust was shown in grades Omsk 20, Omsk 37, and in the grade Erythrospermum 55/94 the moderate
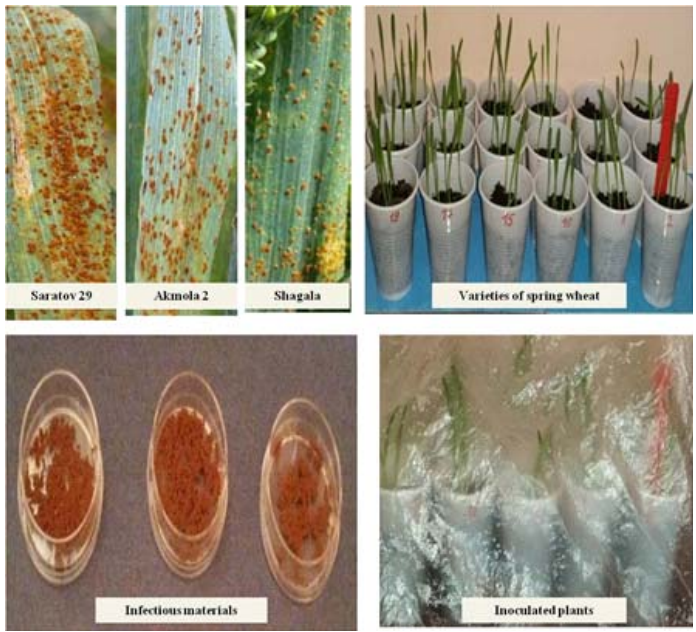

Fig. 1. Methods of determining germ resistance of spring-wheat grades to leaf rust

\section{REFERENCES}

1. Ganiyev M. M., Nedorezkov V.D., Ganiyev P.M., Protection of field cultures, grain cereals, Ufa, BGAU publishing house, 2002; 7-10.

2. Gorlenko M. V., Rubin. B. A., Immunity of plants, Protection and quarantine of plants, 2001; 8: S.16-19.

3. Vedeneyeva M. L., Markelova T.S., Kirillova T.V., Anikeeva N. V. Strategy of selection of disease-resistant grades of wheat in the Volga region.//Agro XXI-. No. 2. - Page 12-13.

4. Kisileva M. I, E.D. Kovalenko E.D, Mitrofanov O. P., Screening of wheat grades of the VIR world collection on resistance to a brown rust of http://cyberleninka .ru/article/n/skriningsortov-pshenitsy-mirovoy- kollektsii-vir-poustoychivosti-k-buroy-rzhavchine, 2015.

5. Knaus, Yulia Konstantinovna., Cytophysiological mechanisms of long resistance to a brown rust of types and soft wheat with introgressirovanny genes: thesis... susceptibility was observed. Other studied grades in a stage of sprouts and adult plants were highly sensitive to an infecting agent of a yellow rust of wheat.

According to laboratory and field researches types of resistance of soft spring-wheat grades are defined. The grades with juvenile and age resistance are of interest as sources of resistance and are a valuable material for selection in immunity to a leaf rust.

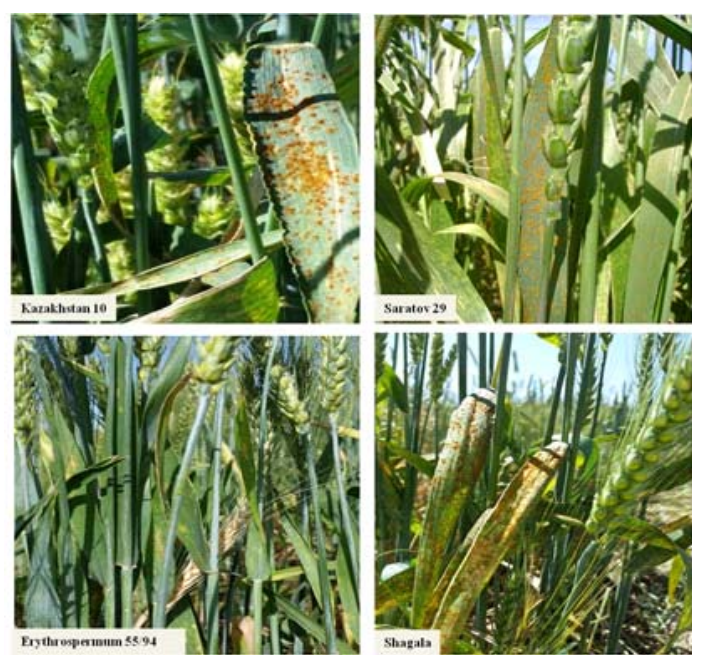

Fig. 2. Stable and susceptible grades of spring-wheat to leaf rust

Candidate of Biology, Moscow, 2009; 225c.

6. Kolmer J.A., Genetics of resistance of wheat to leaf rust//Annu. Rev.Phytopathol. 1996; 34: 435455.

7. Kolmer J.A., Liu J.Q., Virulence and molecular polymorphism in International Collection of the wheat leaf rust fungus Puccinia triticina, II Phytopathology, 2000; 90: 427-436.

8. Konovalova N. E., Semenova L.P., Sorokina G. K., Shchekotkova T.V., Suzdal M.V., Bukanova V. K., A.I., Gorbunov Yu.V., Rogozhina E.M., Solomatin D. A., Koroleva L.A., Schelko L.G., Methodical recommendations about studying of racial structure of activators of a rust of grain cereals. - Moscow: VASHNIL, 1977; 144 pages.

9. Konovalova N. E., Semenova L.P., Sorokina G. K., Shchekotkova T.V., Suzdalskaya M.V., Bukanova V. K., .I., Gorbunov Yu.V., Rogozhina E.M., Solomatin D. A., Koroleva L.A., Schelko L.G., Methodical recommendations about studying of racial structure of activators of a rust of grain cereals. - Moscow: VASHNIL, - 
1977; 144.

10. Kovalenko E.D., A.I., Kiselyov M. I. Pearl., Kolomiyets T.M., Sherbik A.A., Strategy of selection of heat on stability to rust disease, Protection and quarantine of plants, 2012; 9: 812.

11. Mains E.E., Jackson H.S., Physiologic specialization of the leaf rust of wheat Puccinia tritici Eriks, Phytopathology, 1926; 6(2): 89-120.

12. Makarov A.A., Kovalenko E.D., Solomatin D. A., Matorina N. M., Methods of a field and laboratory assessment of nonspecific resistance of plants to diseases//Materials of a scientific seminar "Types of resistance of plants to diseases” St. Petersburg. 2003; 17-24.

13. Makarov A.A., Solomatin D. A., Strizhekozin Yu.A., Laboratory method of detection of partial (racespecific) resistance of wheat to a brown rust//Collection of methodical recommendations about protection of plants. 1998; 148-152.

14. Markelova T.S., Immunological bases and methods of creation of initial material of wheat for selection on resistance to diseases in the Volga region. Avtoref. doctor. page - x. sciences, Saratov, 2007; 54 .

15. McIntosh R.A., History and status of wheat rust//BGRI. Technical Workshop. Cd. Obregon,
16. Sonora, Mexico, March 17-20, 2009. Full Papers and Abstracts. 2009; 1-16.

17. Mikhaylova L.A., Genetics of resistance of wheat to a brown rust//Materials of a scientific seminar "Types of resistance of plants to diseases” St. Petersburg. 2003; 45-60.

18. Peterson R.F., Campbell A.B., Hannah A.E., A diagrammatic scale for estimating rust intensity on leaves and stems of cereals, Canad. J. Res, 1949; 26: 496-500.

19. Plotnikova L.Ya., Shtrubey T.Yu., Efficiency of genes of age resistance of wheat to a brown rust of Lr22b, Lr34, Lr37 in Western Siberia a cytophysiological basis of their action// Vavilovsky the magazine of genetics and selection. 2012; 16(1): 123-131.

20. Roelfs A.P., Singh R.P., Sari E.E., Rust Diseases of Wheat: Concepts and methods of disease management - Mexico, D.F.: CIMMYT, 1992; $81 \mathrm{p}$.

21. Seytkhozhayev A.I., Kolesnikova L.I., Dyusibayeva E.N., Resistance of grain cereals to rust diseases, Materials of the Republican scientific-theoretical conference "Seyfullin Readings-11 Youth and Science”, 2015; 2(1): 51-53. 